\title{
Factors, Outcome, and the Solutions of Supply Chain Finance: Review and the Future Directions
}

\author{
Zericho R Marak * and Deepa Pillai \\ Symbiosis School of Banking and Finance, Symbiosis International (Deemed University), 412115, India; \\ deepa.pillai@ssbf.edu.in \\ * Correspondence: zericho.marak@ssbf.edu.in
}

Received: 19 October 2018; Accepted: 18 December 2018; Published: 21 December 2018

\begin{abstract}
In the current highly competitive and fast-changing business environment, in which the optimisation of all resources matters, creating an efficient supply chain is crucial. Earlier studies on supply chains have focussed on aligning product/services and information flows while neglecting the financial aspects. Due to this, in recent times, importance has been given to align financial flows with the other components of the supply chain. The interest in supply chain finance rose after the financial crisis when the bank loans declined considerably, as the need for better management and the optimisation of working capital became obvious. This paper reviews the articles on supply chain finance based on three themes-factors, outcomes, and solutions-while at the same time providing directions for future research on supply chain finance. This article is unique, as it investigates the factors affecting supply chains according to the existing literature. It also sheds light on the outcome of the supply chain without limiting the discussion only to the benefits. Further, it addresses the question: what are the solutions constituting supply chain finance?
\end{abstract}

Keywords: supply chain management; supply chain finance; working capital; factors; outcomes; solutions; optimisation

\section{Introduction}

In the modern fast-changing business environment, competitive pressures have become more acute. To maintain a competitive advantage and be on top of the game, focus and attention have been given to make supply chains more effective and efficient, in contrast to competing as a single company. A lot of academic research studies have been devoted to improving the physical flow of goods or services and the informational flow of the supply chain. However, the financial aspect of the supply chain has been heretofore neglected (Lamoureux and Evans 2011; Bailey and Francis 2008; Pfohl and Gomm 2009; Caniato et al. 2016). If the supply chain is to be more efficient and the companies are expected to maintain a competitive advantage or even to compete, all the components of the supply chain need to be given proper attention.

Supply chain finance (SCF) became more critical after the financial crisis of September 2008, when the loans from banks and financial institutions receded very drastically. Considerably, other alternative forms of financing, especially trade credit from suppliers, became more demanding. However, an extension of trade credit is subjected to the bargaining power whereby weaker suppliers will be forced to increase the payment period or forcibly delay the repayment (Fabbri and Klapper 2016). This can create risk or disruption in the supply chain (Boissay and Gropp 2007; Coricelli and Masten 2004; Raddatz 2010; Caniato et al. 2016). Therefore, there is a need for the better management and optimisation of working capital in the supply chain which SCF endeavours. SCF has also been touted to improve the accessibility of funds to small and medium enterprises (SMEs). Besides, it also assists with viewing working capital management from the supply chain perspective, rather than a 
single entity perspective. However, although most of the works on SCF deal with working capital, it is important to note that it is not limited to optimising short-term financial flow; it may also cover long-term financing. SCF can create win-win situations for the supply chain (SC) partners. A lot of academic research works have come up in the last few years that address this area of supply chain.

According to Xu et al. (2018), the research on supply chain finance (SCF) can be traced back to the 1970s; for example, Budin and Eapen (1970) worked on the net cash flow that is generated in business operations during a cash-planning period, and the effect of such changes on the policies relating to trade credit and inventories. Haley and Higgins (1973) studied the relationship between trade credit policy and inventory policy. However, the formalisation of the definition of SCF occurred only during the 21st century. According to Pfohl and Gomm (2009), Stemmler and Seuring (2003) were amongst the first ones to use the term SCF where they spoke of the control and optimisation of financial flows induced by logistics. Hofmann (2005) defined SCF as "located at the intersection of logistics, supply chain management, and finance" and as "an approach for two or more organisations in a supply chain, including external service providers, to jointly create value by planning, steering, and controlling the flow of financial resources on an inter-organisational level".

Pfohl and Gomm (2009) defined SCF as the inter-company optimisation of financing and the integration of financing processes with customers, suppliers, and service providers to increase the value of all of the participating companies. Gomm (2010) defined it as "optimising the financial structure and cash flow within the supply chain". The researcher also stated that the objective of SCF is to optimise financing across borders to decrease the cost of capital and increase the speed of cash flows. Further, SCF is defined as "the use of financing and risk mitigation practices and techniques to optimise the management of the working capital and liquidity invested in supply chain processes and transactions" (Global Supply Chain Finance Forum n.d.; Babich and Kouvelis 2018). Thus, this definition added a dimension of risk mitigation to supply chain finance.

It can be seen that the main aim of supply chain finance is to optimise the inter-organisational flow of funds (Hofmann 2005) preferably through the solutions implemented by financial institutions (Camerinelli 2009) or technology service providers (Lamoureux and Evans 2011). The ultimate aim is to align financial flows with other components of the supply chain, i.e., physical and information flow, within the supply chain, improving cash flow from a supply chain perspective (Wuttke et al. 2013b).

As the interest on the SCF grew in the 21st century both in academics and practice, research and contributions to SCF increased. However, there have been differences in the approach to SCF, and thus there emerged different perspectives to the definition of SCF. Gelsomino et al. (2016b) showed that the SCF literature lacked a single definition, and there are two main perspectives to a SCF: financial-oriented perspective, and supply chain-oriented perspective. There is another perspective to SCF, which is called the 'buyer driven-oriented perspective', which mainly focusses on 'reverse factoring', and can be considered as a subset of the 'finance-oriented perspective'. The finance-oriented perspective considers SCF to be a set of (innovative) financial solutions and concentrates on short-term financing and particularly on the financing solutions relating to receivables and payables. The role of financial institutions or banks concerning SCF solutions is mandatory in this perspective. The 'supply chain-oriented perspective' of SCF includes, within the SCF framework, the optimisation of the inventories along the chain (or at least between the customer and the supplier) to reduce the working capital. Therefore, the need for financing or working capital shifts to the player with a better availability of cash and/or a lower financing cost. Further, it does not limit SCF to only short-term financing, and there is no mandatory role of financial institutions and banks in SCF solutions. Thus, it can be said that the 'supply chain perspective' of SCF has a broader view of SCF than the 'finance-oriented perspective'.

There have been literature review articles relating to supply chain finance, e.g., Gelsomino et al. (2016b) and Xu et al. (2018). Gelsomino et al. (2016b) did a review of the existing literature based on three themes, i.e., concept and definitions, expected benefits, and SCF initiatives in place. Although the expected benefits have been touched on by Gelsomino et al. (2016b), the outcome or consequences 
of SCF do not just pertain to benefits as evident from the literature; as such, the current researchers felt the need to explore the outcome. Xu et al. (2018) performed a bibliometric analysis of the SCF literature. They provided bibliometric information on the published articles relating to SCF, including the identification of four research clusters of SCF. However, they did not touch upon the main focus of this current article, i.e., the factors, outcomes, and solutions of SCF. By focusing on three themes-the factors, outcomes, and solutions of SCF-this paper will contribute to the existing literature.

\section{Methodology}

This paper is more oriented towards a structured literature review, as it focusses on the systematic method, meaning a detailed plan of the path and steps undertaken to select, scan, and analyse the literature to reduce biases and improve transparency (Tranfield et al. 2003; Hofmann and Bosshard 2017). A structured literature review is generally applied to close the research-practice gap (Touboulic and Walker 2015; Hofmann and Bosshard 2017) and for developing the propositions and future research directions. This article adapts the procedures used by Denyer and Tranfield (2009) and Hofmann and Bosshard (2017), as shown in Figure 1.

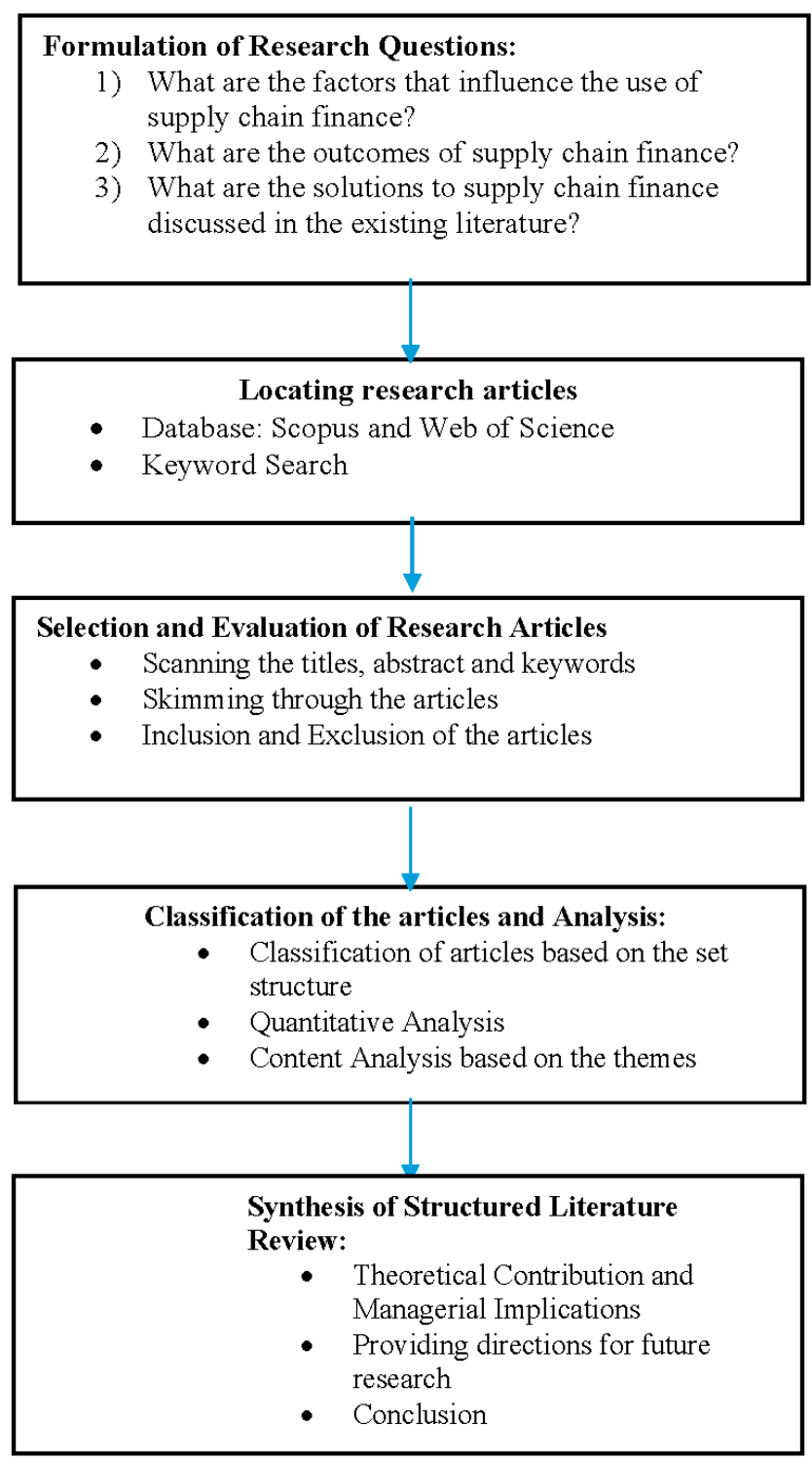

Figure 1. Literature review procedure (adapted with permission from Hofmann and Bosshard 2017). 


\section{Formulation of Research Questions}

This literature review is motivated by the following three research questions:

RQ1: What are the factors that influence the use of supply chain finance?

RQ2: What are the outcomes of supply chain finance?

RQ3: What are the solutions to supply chain finance that have been discussed in the existing literature?

The article aims to answer these three research questions, and the researchers believe that answering these questions will lead to the contribution of this article to the supply chain finance literature. Therefore, the paper focuses on the three themes, i.e., the factors, outcomes, and solutions of supply chain finance.

\section{Locating the Research Articles}

Articles were searched from the scientific research databases of Scopus and Web of Science using a string of keywords, i.e., "Supply Chain Finance" OR "Supply Chain Financing" OR "Financial Supply Chain" OR "Financial Value Chain". From the search results, conference proceedings were removed. Scopus produced a result of 182 articles and Web of Science produced a result of 45 search results. This review article concentrated specifically on three themes:

a. Factors influencing supply chain finance

b. The outcome of supply chain finance

c. Solutions of supply chain

First of all, the abstract of the articles was read; then, the body of the articles was also carefully read, and only those articles fitting to the themes were selected for final review. The majority of the articles in the Web of Science were overlapping with that of Scopus. It is understandable that the Web of Science indexed a lesser number of journals, and most of them are listed in Scopus as well. Finally, 70 articles were considered for the review. The process of the identification, screening, derivation of eligibility documents, and final inclusion of the documents for review is given in Figure 2.

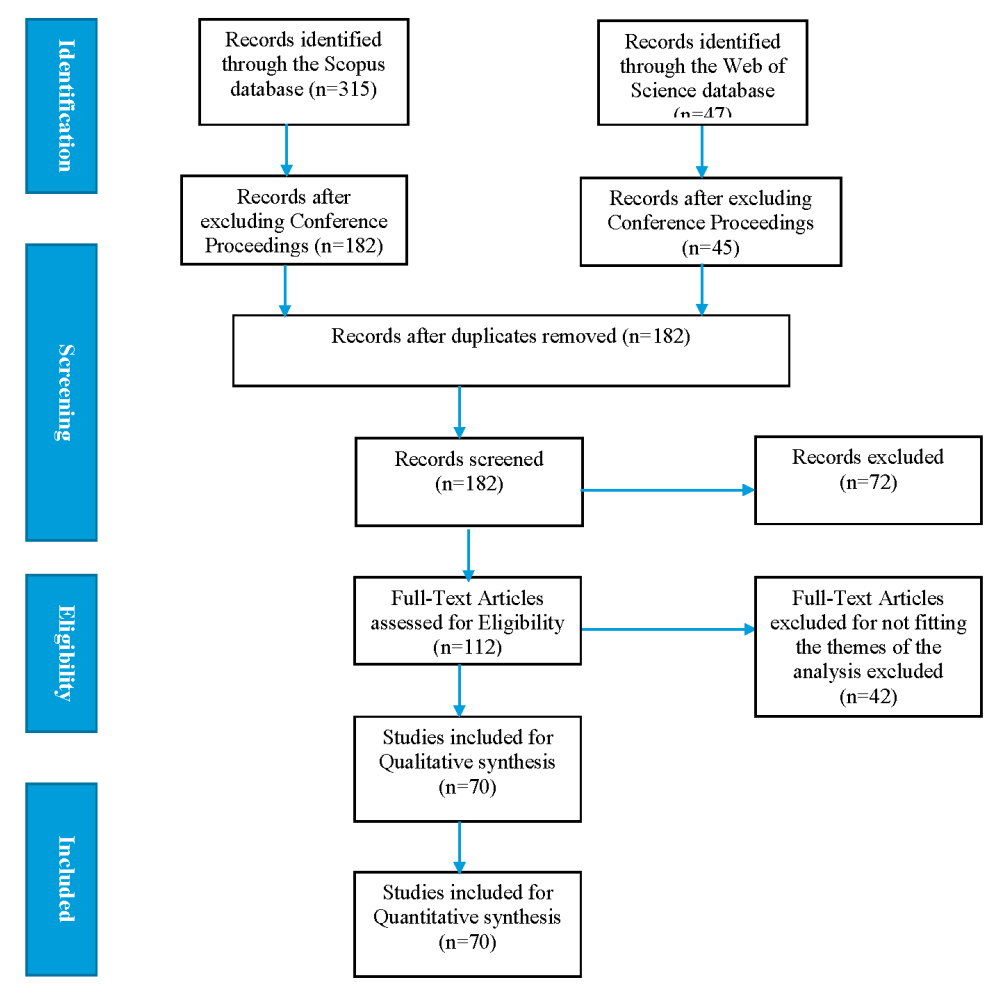

Figure 2. Procedure for locating, screening, and selecting documents. 


\section{Classification of the Articles}

The classification of selected and collected literature is done as per the format shown in Table 1. Initially, the findings of the articles reviewed were grouped in the head 'findings'. However, whether the findings were related to 'factors' or/and 'outcomes' was further analysed. Thus, separate heads for 'factors' and 'outcomes' were created. The rest of the heads under which categorisation was done are shown in Table 1, which was completed using Microsoft Excel.

Table 1. Categorisation of the articles.

\begin{tabular}{|c|c|}
\hline Category & Information \\
\hline Author(s) & Contributor(s) to the article \\
\hline Source & Journal or book in which the considered article was published \\
\hline Year & Year in which the article was published \\
\hline Volume and issue & Volume and issue of the articles reviewed \\
\hline Country & Country of the corresponding author's affiliation \\
\hline Keywords & Keywords stated by the articles to help with visibility \\
\hline Objectives of the paper & Aims/objectives/research questions of the paper \\
\hline Methodologies & $\begin{array}{l}\text { Methodologies used in the study. If multiple methodologies were used, } \\
\text { then all of the methodologies were recorded in the first round. Then, for the } \\
\text { final categorisation, only the main methodology was considered. }\end{array}$ \\
\hline Findings & Findings/results/outcomes of the paper \\
\hline Factors & $\begin{array}{l}\text { Forces or factors that are discussed explicitly or implicitly to influence supply } \\
\text { chain finance }\end{array}$ \\
\hline Outcome & $\begin{array}{l}\text { The consequences or outcome of supply chain finance, whether positive or } \\
\text { negative and discussed explicitly or implicitly in the literature }\end{array}$ \\
\hline Solutions & $\begin{array}{l}\text { Various instruments or initiatives or modes that help facilitate supply chain } \\
\text { finance }\end{array}$ \\
\hline Limitations and gaps & $\begin{array}{l}\text { Limitations/gaps/future directions mentioned in the paper or that can be } \\
\text { observed in the paper }\end{array}$ \\
\hline
\end{tabular}

\section{Synthesis of Structure Literature Review}

This article does not claim to cover the entire literature on the supply chain finance exhaustively; instead, based on the articles reviewed, it provides a snapshot of the supply chain finance regarding three themes: factors, outcomes, and solutions. Also based on the analysis and review, it provides a path for future research work.

\section{Results and Findings}

\subsection{Methodologies}

Figure 3 shows most of the published articles have followed an analytical modelling methodology (37 articles), followed by case studies ( 15 articles). These two methodologies make up $74 \%$ of the total articles reviewed. 


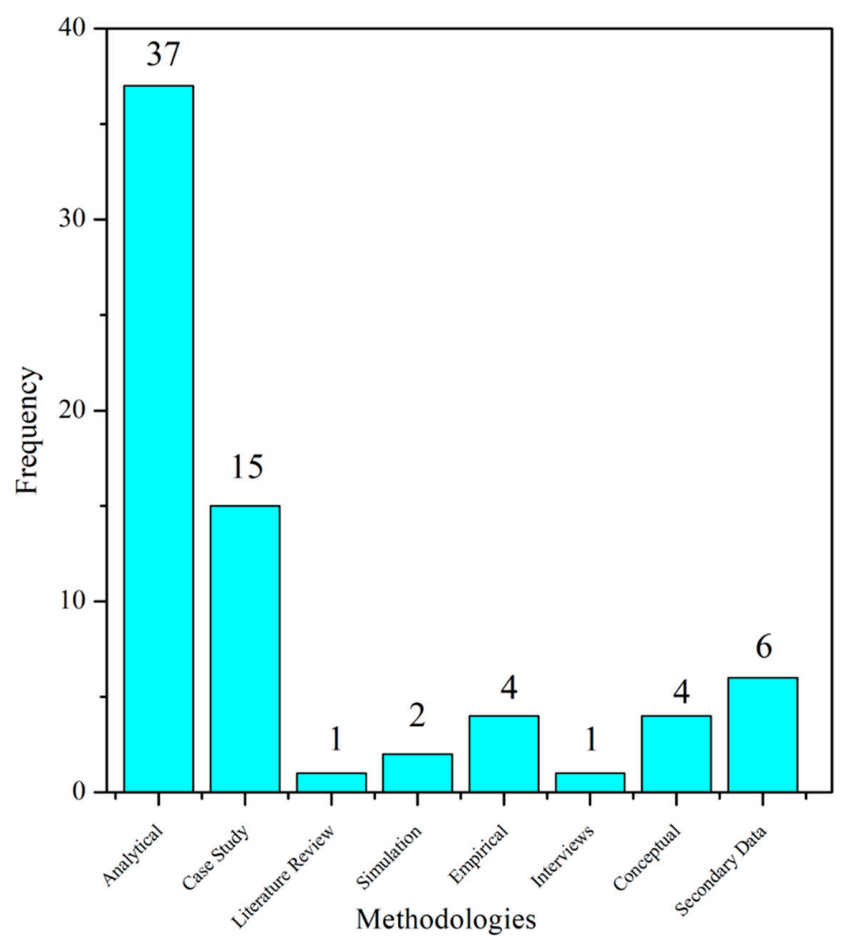

Figure 3. Methodologies of the reviewed articles.

\subsection{Year of Publication}

Figure 4 shows that the years with the highest numbers of published articles were in 2018 (13 articles), 2017 (13 papers), and 2016 (12 papers). It is expected that by the end of 2018, the number of publications in 2018 will exceed that of the previous year. The number of publications has increased considerably in the last four years, showing that supply chain finance has been of high academic interest.

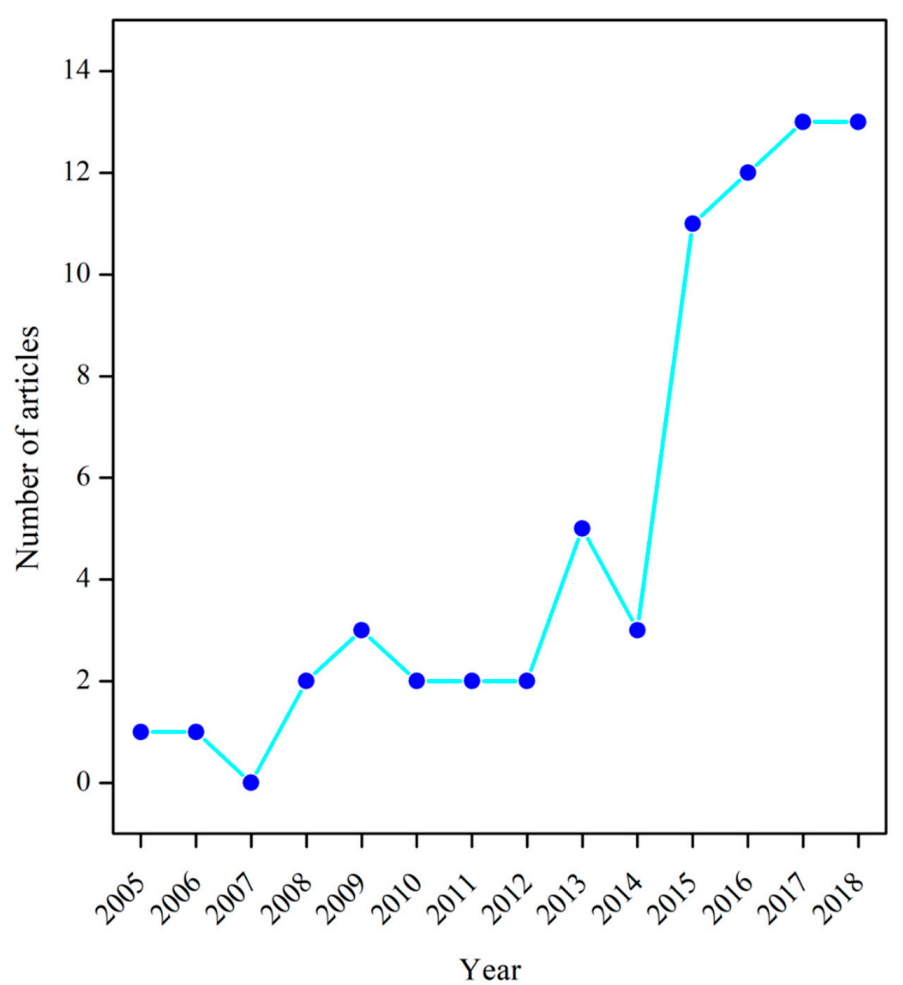

Figure 4. Number of articles per year. 


\subsection{Source of Publication and Top Cited Papers}

The highest number of reviewed articles is found in International Journal of Physical Distribution and Logistics Management (six papers), followed by International Journal of Production Economics (three papers), Revista de la Facultad de Ingeniería U.C.V (three papers), Supply Chain Forum (three papers), Sustainability (three papers), Applied Stochastic Models in Business and Entity (two papers), The European Journal of Operations Research (two papers), The International Journal of Applied Business and Economic Research (two papers), The International Journal of Logistics Research and Applications (two papers), The International Journal of Production Research (two papers), The International Journal of Simulation: Systems, Science, and Technology (two papers), Manufacturing and Service Operations Management (two papers), and Supply Chain Management (two papers). These articles cover $50 \%$ of the total articles reviewed, showing how diverse the sources of the publications have been. Table 2 shows the distribution of the sources of articles in terms of the 'Name of the Journal' and the number of articles reviewed.

Table 3 also provides the top 10 cited papers from both Scopus and Web of Science.

Table 2. Distribution of reviewed articles by sources of publication.

\begin{tabular}{|c|c|}
\hline Name of the Journal & No. of Articles \\
\hline International Journal of Physical Distribution and Logistics Management & 6 \\
\hline International Journal of Production Economics & 4 \\
\hline Revista de la Facultad de Ingeniería & 3 \\
\hline Supply Chain Forum & 3 \\
\hline Sustainability & 3 \\
\hline Applied Stochastic Models in Business and Industry & 2 \\
\hline European Journal of Operational Research & 2 \\
\hline International Journal of Applied Business and Economic Research & 2 \\
\hline International Journal of Logistics Research and Applications & 2 \\
\hline International Journal of Production Research & 2 \\
\hline International Journal of Simulation: Systems, Science, and Technology & 2 \\
\hline Manufacturing and Service Operations Management & 2 \\
\hline Supply Chain Management & 2 \\
\hline Advances in Transportation Studies & 1 \\
\hline Agro Food Industry Hi-Tech & 1 \\
\hline Amfiteatru Economic & 1 \\
\hline Asian Journal of Law and Society & 1 \\
\hline Asia-Pacific Journal of Operational Research & 1 \\
\hline Boletin Tecnico/Technical Bulletin & 1 \\
\hline Business Process Management Journal & 1 \\
\hline International Federation for Information Processing (IFIP) & 1 \\
\hline International Journal of Integrated Supply Management & 1 \\
\hline International Journal of Islamic and Middle Eastern Finance and Management & 1 \\
\hline International Journal of Logistics Systems and Management & 1 \\
\hline International Journal of Operations and Production Management & 1 \\
\hline International Journal of Revenue Management & 1 \\
\hline International Journal of Services, Technology, and Management & 1 \\
\hline Journal of Applied Accounting Research & 1 \\
\hline Journal of Business Logistics & 1 \\
\hline Journal of Corporate Finance & 1 \\
\hline Journal of Cases on Information Technology & 1 \\
\hline Journal of Industrial and Management Optimization & 1 \\
\hline Journal of Management Information Systems & 1 \\
\hline Journal of Purchasing and Supply Management & 1 \\
\hline Journal of Modelling in Management & 1 \\
\hline Journal of Supply Chain Management & 1 \\
\hline Journal of the Operational Research Society & 1 \\
\hline Journal of Shanghai Jiaotong University (Science) & 1 \\
\hline Logistics and Supply Chain Innovation: Bridging the Gap between Theory and Practice & 1 \\
\hline
\end{tabular}


Table 2. Cont.

\begin{tabular}{lc}
\hline Name of the Journal & No. of Articles \\
\hline Logistics Research & 1 \\
Management Science & 1 \\
Omega & 1 \\
Metallurgical and Mining Industry & 1 \\
OR Spectrum & 1 \\
Research Journal of Applied Sciences, Engineering, and Technology & 1 \\
Research Journal of Applied Sciences, Engineering, and Technology & 1 \\
Shenzhen Daxue Xuebao (Ligong Ban)/Journal of Shenzhen University Science and Engineering & 1 \\
Xitong Gongcheng Lilun yu Shijian/System Engineering Theory and Practice & 1 \\
\hline
\end{tabular}

Table 3. Top 10 cited papers from Scopus and Web of Science.

\begin{tabular}{cccc}
\hline Scopus & & \multicolumn{2}{c}{ Web of Science } \\
\hline Author(s) & Times Cited & Author(s) & Times Cited \\
\hline Pfohl and Gomm (2009) & 63 & Raghavan and Mishra (2011) & 37 \\
Randall and Farris (2009) & 63 & Wuttke et al. (2013a) & 35 \\
Raghavan and Mishra (2011) & 58 & Shang et al. (2009) & 20 \\
Wuttke et al. (2013a) & 43 & Johnson (2008) & 20 \\
Wuttke et al. (2013b) & 34 & Yan and Sun (2013) & 17 \\
Gomm (2010) & 31 & Wuttke et al. (2016) & 8 \\
Johnson (2008) & 30 & Van der Vliet et al. (2015) & 7 \\
More and Basu (2013) & 29 & Yan et al. (2014) & 7 \\
Fairchild (2005) & 26 & Yan and Sun (2015) & 6 \\
Shang et al. (2009) & 25 & Chen et al. (2017) & 5 \\
\hline
\end{tabular}

\subsection{Country}

Figure 5 depicts the contributing countries to the supply chain finance literature. The highest contribution has come from China (29 articles), followed by Germany (eight articles), the United States of America (USA) (eight articles), and Switzerland (five articles). China alone has contributed about $40 \%$ of the total reviewed papers. In comparison, all of the above-mentioned countries-i.e., China, Germany, the USA, and Switzerland-contributed $77 \%$ of the total articles reviewed. Among these countries, there are similarities and differences in the patterns of contribution to the field, e.g., China and Germany's main contributions have come in the form of analytical articles, followed by case studies and conceptual articles. However, in the case of China, around $86 \%$ (25 out of 29 ) of the articles have been analytical, whereas in the case of Germany, it is $50 \%$ (four out of eight). With regards to the USA, the majority of the articles have been in the form of studies based on secondary data (five out of eight), and in the case of Switzerland, more articles have been in the form of empirical studies based on surveys. It is interesting to note that there is no article present in the sample that is considered for the review from the regions such as Africa and South America. It can be said that there is still a lack of exploration and studies on supply chain finance in certain parts of the globe. 


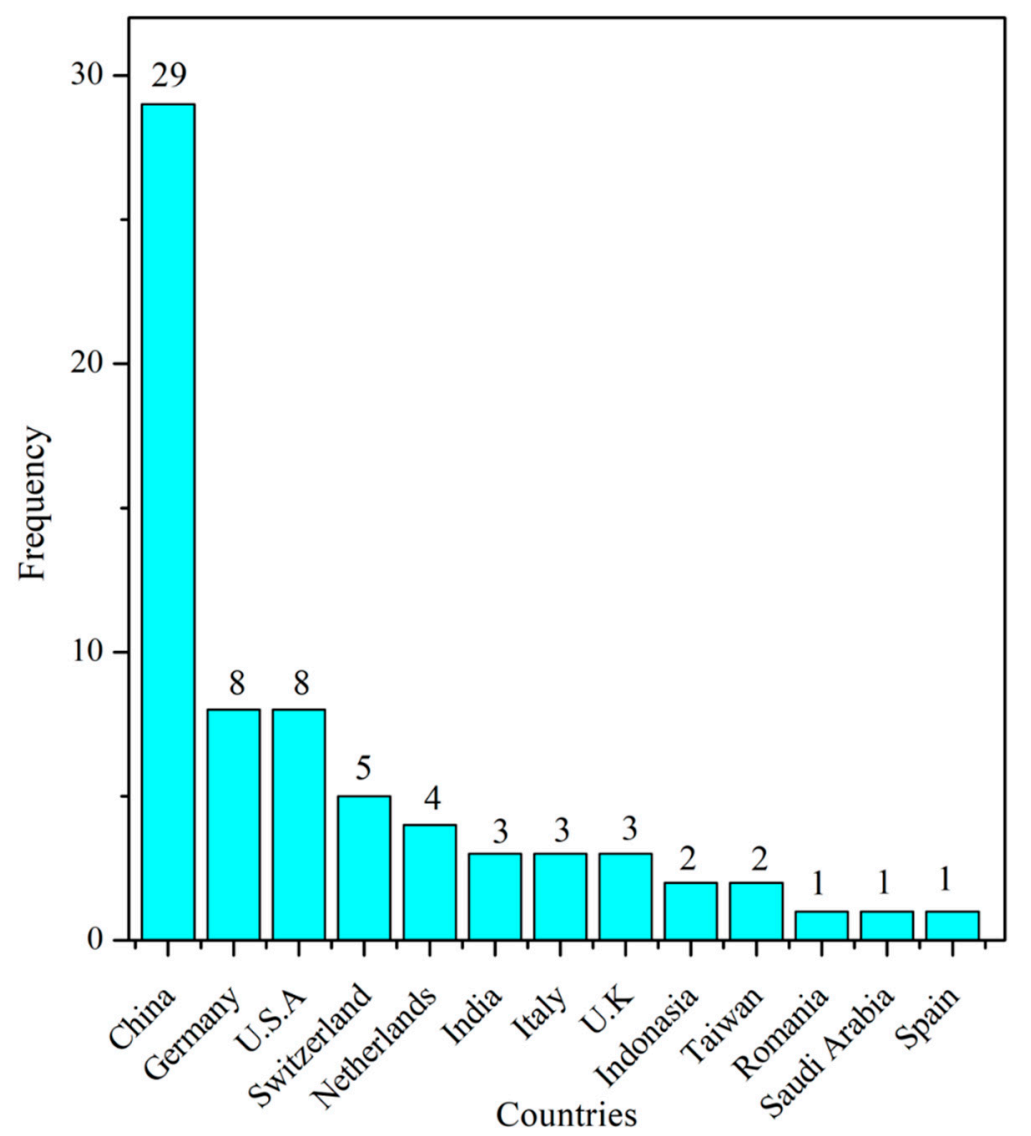

Figure 5. Contributing countries.

\subsection{Factors Influencing the Acceptance of Supply Chain Finance}

Several researchers discussed the varied number of factors that are expected to affect the acceptance of supply chain finance amongst firms in the supply chain. The most widely discussed factors in the literature are collaboration, the automation of trade process/level of digitalisation, trust, reputation, image or track record, bargaining power, coordination, financing cost, information sharing, cooperation, availability of external financing, financial attractiveness, supply chain integration, credit rating, dependence, objectives, information visibility, workforce, and joint decision making.

Collaboration is one of the important factors that have been widely discussed as having an effect on the use of SCF (Fairchild 2005; Pfohl and Gomm 2009; Wuttke et al. 2013a, 2013b; Popa 2013; Silvestro and Lustrato 2014; Wandfluh et al. 2016; Caniato et al. 2016; Protopappa-Sieke and Seifert 2017; Zhang 2016; Blackman and Holland 2006). It is clearly understood that SCF is a collaborative form of financing, and thus, collaboration as a factor plays an important role in its use and successful adoption. Not only inter-firm collaboration, but intra-firm collaboration as well, i.e., between departments of the organisation, is found to be essential for SCF (Wandfluh et al. 2016; Caniato et al. 2016). Trust is an integral part of supply chain financing, and several researchers have stressed that trust is essential (Randall and Farris 2009; Wuttke et al. 2013b; Liebl et al. 2016; Martin 2017; Blackman and Holland 2006; Karyani et al. 2015; Ta et al. 2018). Martin (2017) stated that trust exists when there is honesty and benevolence. The parties involved in the supply chain need to maintain trustworthiness, and Ta et al. (2018) mentioned that changes in the trustworthiness can play a crucial role in maintaining a relationship. It is important for the SC partners to maintain openness (Randall and Farris 2009) and fairness (Chen et al. 2017). In line with this, several articles also stressed reputation, image, or track record (Iacono et al. 2015; Liebl et al. 2016; Chen 2016; Zheng and Zhang 2017). While Iacono et al. (2015) showed the importance of a bank's track record in reverse factoring, Liebl et al. (2016) stated that buyers extend 
reverse factoring to the suppliers with a proper track record. Chen (2016), while working on the supply chain financing and the function and role of logistics enterprises, pointed out the need for the focal company to have a good reputation, i.e., the logistics company in this case. Zheng and Zhang (2017) viewed the SCF for Business to Business (B2B) cross-border e-commerce business, and demonstrated that reputation is essential. The higher the reputation, image, or track record, the better the trustworthiness and facilitation of SCF will be. Besides, the SC partners need to maintain cooperation (Jiang et al. 2016; Zheng and Zhang 2017; Yu and Zhu 2018) and coordination (Shang et al. 2009; Silvestro and Lustrato 2014; Gomm 2010; Yu and Ma 2015), as well as share risk, reward (Randall and Farris 2009), and information (Silvestro and Lustrato 2014; Wandfluh et al. 2016; Jiang et al. 2016; Ding et al. 2017); and jointly make decisions (Raghavan and Mishra 2011; Wuttke et al. 2013b). Carnovale and Yeniyurt (2015) demonstrated that the supply chain network is crucial for the firm's performance, and a well-connected network is associated with better performance.

Power is defined as "the ability of one firm to influence the actions and intentions of another" (Maloni and Benton 2000; Martin 2017), and it also plays a role in SCF, which several articles have highlighted (Wuttke et al. 2013b; Caniato et al. 2016; Wuttke et al. 2016; Protopappa-Sieke and Seifert 2017; Chen et al. 2017). In the literature, power has been mostly associated with the bargaining power of the buyer (focal company), as the buyer has been assumed to be a larger enterprise to their supplier. Caniato et al. (2016) used a term called "financial attractiveness" to refer to the bargaining power of the focal company to the financial institutions, which help in offering SCF solutions to their supplier, as in the case of reverse factoring. If the bargaining power of the focal firm, which is the buying firm in this case, is high, the buyer tends to reduce the purchase prices, whereas if it is low, then the buyer will try to improve the relationship with key suppliers. Similarly, the dependence of one firm on another, which is the reciprocal of power, influences the supply chain financing (Wuttke et al. 2013a; Martin 2017). Wuttke et al. (2013a) goes further, and divided dependence into 'pooled dependence' and 'dispersion of dependence'.

Caniato et al. (2016) mentioned that there is a plurality of objectives behind adopting SCF, i.e., improving the adopter's financial performance and securing the supply chain, and these objectives play a crucial role in SCF adoption. Other studies by Iacono et al. (2015), Liebl et al. (2016), and Zhou et al. (2018) also confirmed the influence of objectives on SCF.

The level of automation of trade processes or the level of digitalisation is another important factor that the literature stressed (Fairchild 2005; Wuttke et al. 2013b; Gomm 2010; Caniato et al. 2016; Chen 2016; Blackman and Holland 2006; Zhou et al. 2018). The automation of trade processes may occur in various ways, e.g., electronic invoicing, reconciliation databases, electronic payment systems, trade platforms, and forecasting platforms, among others. These technologies or automation may be offered by banks or financial service providers (Silvestro and Lustrato 2014), or it may need the involvement of another party in the supply chain financing, i.e., a technology service provider (TSP) (Martin and Hofmann 2017). TSP may act as a bridge between the funders and buyers, as well as the sellers. Due to the significance of technologies and vast opportunities arising out of it, Fintechs are also starting to get involved in SCF (Tsai and Peng 2017). Although for the traditional SCF solutions, a higher level of automation may not be needed, for innovative SCF solutions, a higher level of automation may be required. The visibility of information across the trade process and the supply chain is desirable. In supply chain financing, the same is desired (Silvestro and Lustrato 2014; Jiang et al. 2016), and the level of automation can increase the visibility.

The studies of Yan and Sun (2013) and Martin (2017) highlighted that the availability of external financing affects the supply chain partners' participation in SCF, and the easier accessibility of external financing may reduce the use of SCF.

The frequency and volume of transactions matter in supply chain finance, as the transactions need to be financially attractive, especially for the financial service provider. However, the same may hold true for the buyer as well, e.g., in the case of reverse factoring, where the buyer may be motivated 
to use reverse factoring only for those suppliers with an attractive enough volume of receivables (Pellegrino et al. 2018; Hofmann and Zumsteg 2015; Iacono et al. 2015).

Supply chain integration has also been discussed as an influence on supply chain financing. Wuttke et al. (2013a) considered it as an umbrella that includes the joint decision, joint investment, real-time sharing of operational information, regular meetings, engagement in collaborative planning, and sharing cost information, among others. Not only should the supply chain partners be integrated upstream and downstream, but SC integration should also exist among financial service providers (FSPs) as well.

The talent, skill, and expertise of the workforce may also affect supply chain financing. Jiang et al. (2016) input it in a factor called 'basic condition', which consisted of personnel quality, and other factors similar to this concept include innovation ability, technical ability, quality, and financial condition.

Yan and Sun (2013) performed several analytical methodologies such as the Stackelberg game, coordination analysis, and numerical analysis, and showed that an "appropriate financing scheme/solution" matters, and influences the retailer's decision to order.

The literature has discussed several factors influencing SCF. However, it may be possible to classify them into broader groups based on similar characteristics. It is understandable that many of these factors will be overlapping between categories, but for simplification and clearer understanding, classification of the factors is desirable. Table 4 shows the categorisation of these factors into five categories, i.e., operational factors, financial factors, relationship factors, and informational factors.

Table 4. Categorisation of factors.

\begin{tabular}{|c|c|c|c|c|}
\hline $\begin{array}{l}\text { Operational } \\
\text { Factors }\end{array}$ & Financial Factors & Relationship Factors & Technological Factors & $\begin{array}{l}\text { Informational } \\
\text { Factors }\end{array}$ \\
\hline Coordination & $\begin{array}{c}\text { Financial } \\
\text { attractiveness }\end{array}$ & Collaboration & $\begin{array}{c}\text { Automation of trade } \\
\text { process/level of } \\
\text { digitalisation }\end{array}$ & Information sharing \\
\hline $\begin{array}{l}\text { Frequency and } \\
\text { volume of } \\
\text { transactions }\end{array}$ & Financing cost & Trust & & Information visibility \\
\hline Objectives & $\begin{array}{c}\text { Availability of } \\
\text { external financing }\end{array}$ & Bargaining power & & Reputation/image \\
\hline \multirow[t]{5}{*}{ Workforce } & Credit rating & Cooperation & & \\
\hline & $\begin{array}{c}\text { Appropriate } \\
\text { financing } \\
\text { scheme/solutions }\end{array}$ & Dependence & & \\
\hline & & Joint decision making & & \\
\hline & & Shared risk and reward & & \\
\hline & & Supply chain network & & \\
\hline
\end{tabular}

\subsection{The Outcome of Supply Chain Financing}

One of the benefits of SCF that the literature has widely highlighted is the reduction of cost of financing (Van der Vliet et al. 2015; Iacono et al. 2015; Gelsomino et al. 2016b; Zheng and Zhang 2017; Ding et al. 2017; Babich and Kouvelis 2018; Yu and Zhu 2018; Yang et al. 2018). It helps to facilitate offering finance at a lower cost to the SC partners, who generally are not privileged to receive capital at lower cost. It leads to financial service providers extending finance at lower interest rates. Supply chain finance not only facilitates a lower cost of financing, it also helps reduce the overall cost in the supply chain, e.g., cost of producing and delivering goods/services (Blackman and Holland 2006; Iacono et al. 2015; Gelsomino et al. 2016b; Jiang et al. 2016; Liu and Wen 2017; Babich and Kouvelis 2018). SCF has been widely touted to offer solutions to the problems faced by SMEs in availing finance; the literature on SCF revealed that SCF improves the accessibility to funds, particularly for smaller SC partners (Suayb Gundogdu 2010; Wang et al. 2012; Yan and Sun 2015; Hofmann and Zumsteg 2015; 
Liu and Wen 2017; Ding et al. 2017; Chen and Wen 2017; Zheng and Zhang 2017; Li et al. 2011). The major problems in approaching working capital optimisation from a single-company perspective involve larger enterprises exercising their bargaining power and optimising the working capital at the expense of other enterprises in the supply chain, which can cause cash flow risk and disruptions in the supply chain. SCF, on the other hand, helps reduce cash flow risk (Wuttke et al. 2013b; Jiang et al. 2016; Martin 2017; Yan and Sun 2015; Gelsomino et al. 2016b; Liu and Wen 2017) and disruptions in the supply chain (Blackman and Holland 2006; Wuttke et al. 2013b; Jiang et al. 2016). It helps unlock and improve the working capital position, e.g., in factoring, reverse factoring, inventor financing, or warehouse financing, a supplier can avail the needed funds before the payment period. Although financial institutions may need to offer to fund at lower rates, SCF ensures an increase in transactions (Hofmann and Zumsteg 2015; Jiang et al. 2016), and helps increase revenue and income for FSPs (Iacono et al. 2015; Zheng and Zhang 2017). Several articles discussed the ability of SCF to enhance the profitability of the individual enterprises as well as that of the supply chain (Wang et al. 2012; Hofmann and Zumsteg 2015; Yan and Sun 2015; Grüter and Wuttke 2017; Bi et al. 2018a; Yu and Zhu 2018; Zhou et al. 2016). There are also other articles that merely touched on the benefits as improving the financial performance (Gomm 2010; Yan et al. 2014; Shi and Wang 2015; Caniato et al. 2016; Carnovale and Yeniyurt (2015); Zhang 2016; Liu and Wen 2017). It is understandable that all of the above-discussed points contribute to the overall financial performance. Pfohl and Gomm (2009) stated that SCF affects the firms by influencing three areas: volume, cost, and duration. The solutions will affect one or more of the dimension(s), and some of the solutions will have a greater effect than the other (also see Gelsomino et al. 2016b).

The visibility of information in the chain is essential for the efficiency and effectiveness of the chain, and SCF aids in reducing information asymmetry in the supply chain (Fairchild 2005; Hofmann and Zumsteg 2015; Ding et al. 2017; Gelsomino et al. 2016b; Li 2017; Song et al. 2018). Several researchers are also of the view that supply chain finance also helps reduce financing risk (Wang et al. 2012; Tsai and Peng 2017). While Wang et al. (2012) stated that SCF can reduce the financing risk for the commercial banks, Tsai and Peng (2017) approached the reduction of financing risk from perspective of the larger enterprise offering loans to the suppliers through online SCF platforms. The main reason for the reduction of risk for larger enterprise as per Tsai and Peng (2017) is due to greater familiarity with their suppliers. Although the approach may be different, nevertheless, SCF can help reduce the financing risk for the finance provider.

Supply chain finance also helps to improve the collaboration between functional departments within the firm, as well as that between enterprises (Bi et al. 2018a; Bi et al. 2018b; Yang et al. 2018). It also helps improve the coordination in the supply chain (Huff and Rogers 2015; Bi et al. 2018a; Bi et al. 2018b). In fact, it improves the relationship in the chain by reducing the conflicts and issues and improving collaboration and coordination.

Some of the articles discussed SCF as improving the overall supply chain (Yu and Ma 2015; Protopappa-Sieke and Seifert 2017; Chen et al. 2017). It may be said that SCF offers a win-win situation for all of the supply chain partners. Overall, it can be said that SCF provides both financial and non-financial benefits.

On the other hand, there are also articles that discussed the possible negative effects of SCF. The major issues that could arise from SCF are risk, uncertainty, and vulnerability. Johnson (2008) demonstrated that risk/uncertainty/vulnerability can occur due the leakage of documents, as supply chain partners may be transacting through financial institutions. The researchers also characterised the threat of loss by examining search patterns in peer-to-peer networks, and also showed the linkage between firm visibility and threat activity. Karyani et al. (2015) stated that if there is a congestion of cash flow in one of the perpetrators, it will cause a ripple effect on the other partners of the supply chain as well. Martin (2017) found that suppliers may also face uncertainty on future terms besides being uncertain about buyers to offer them a financing alternative or solutions. 


\subsection{Supply Chain Finance Solutions}

Supply chain finance is not a single solution-based mode of financing. As it is a medium to optimise the flow of funds and cover the supply chain, various solutions or instruments make up the SCF solutions. Table 5 shows various SCF solutions discussed in the literature.

Table 5. Some of the widely discussed solutions in the literature.

\begin{tabular}{|c|c|c|c|}
\hline Solutions & Definition & Source & $\begin{array}{l}\text { Frequency } \\
\text { in the } \\
\text { Sample }\end{array}$ \\
\hline Reverse Factoring & $\begin{array}{l}\text { In reverse factoring, the buyer sells } \\
\text { the accounts payables and works } \\
\text { together with the supplier and the } \\
\text { banks to optimise the flow of funds. }\end{array}$ & Liebl et al. (2016) & 7 \\
\hline $\begin{array}{l}\text { Accounts Receivables } \\
\text { Financing }\end{array}$ & $\begin{array}{l}\text { Accounts receivable financing refers } \\
\text { to the act of borrowing from a } \\
\text { commercial bank with the accounts } \\
\text { receivable that have not yet been } \\
\text { received. }\end{array}$ & $\begin{array}{l}\text { Ramezani et al. (2014); } \\
\text { Wang (2017) }\end{array}$ & 5 \\
\hline $\begin{array}{l}\text { Purchase Order } \\
\text { Financing }\end{array}$ & $\begin{array}{l}\text { "Purchase order financing allows } \\
\text { banks to offer loans to suppliers by } \\
\text { considering the value of purchase } \\
\text { orders issued by reputable buyers, } \\
\text { and assessing the risk of the supplier } \\
\text { delivering the order successfully." }\end{array}$ & Babich and Kouvelis (2018) & 5 \\
\hline $\begin{array}{l}\text { Agricultural Supply } \\
\text { Chain Finance }\end{array}$ & $\begin{array}{l}\text { A supply chain financing generally } \\
\text { of pre-harvest, trade services } \\
\text { financing, and post-harvest, which is } \\
\text { applied in the agriculture sector. }\end{array}$ & $\begin{array}{c}\text { Suayb Gundogdu (2010); } \\
\text { Li et al. (2011); Karyani et al. } \\
\text { (2015); }\end{array}$ & 5 \\
\hline Factoring & $\begin{array}{l}\text { "Factoring is a type of supplier } \\
\text { financing in which firms sell their } \\
\text { creditworthy accounts receivable at a } \\
\text { discount (generally equal to interest } \\
\text { plus service fees), and receive } \\
\text { immediate cash." }\end{array}$ & Klapper (2006) & 4 \\
\hline Online SCF Platform & $\begin{array}{l}\text { An online platform that facilitates in } \\
\text { networking the parties involved in } \\
\text { supply chain finance (SCF). }\end{array}$ & $\begin{array}{l}\text { Hofmann and Zumsteg } \\
\text { (2015); Martin and Hofmann } \\
\text { (2017); Gao et al. (2018) }\end{array}$ & 5 \\
\hline Inventory Financing & $\begin{array}{l}\text { A short-term loan from a financial } \\
\text { institution to finance inventories. }\end{array}$ & Caniato et al. (2016) & 4 \\
\hline $\begin{array}{l}\text { Warehousing } \\
\text { Financing }\end{array}$ & $\begin{array}{l}\text { Warehouse financing means that } \\
\text { co-operators mortgage their goods in } \\
\text { warehouses for pledge loans. }\end{array}$ & Jiang et al. (2016) & 4 \\
\hline $\begin{array}{l}\text { Buyer Direct } \\
\text { Financing }\end{array}$ & $\begin{array}{l}\text { In buyer direct financing, the buyer } \\
\text { (manufacturer) issues both sourcing } \\
\text { contracts and loans directly to the } \\
\text { suppliers. }\end{array}$ & Babich and Kouvelis (2018) & 4 \\
\hline $\begin{array}{l}\text { Vendor-Managed } \\
\text { Inventory }\end{array}$ & $\begin{array}{l}\text { "The supplier is given the freedom to } \\
\text { plan its own production and decide } \\
\text { upon the replenishment schedule as } \\
\text { long as the agreed customer service } \\
\text { levels are met. This enables suppliers } \\
\text { to stabilise their production and to } \\
\text { optimise the transportation cost" }\end{array}$ & $\begin{array}{l}\text { Waller et al. (1999); } \\
\text { Claassen et al. (2008) }\end{array}$ & 3 \\
\hline
\end{tabular}


Table 5. Cont.

\begin{tabular}{|c|c|c|c|}
\hline Solutions & Definition & $\begin{array}{r}\text { Fre } \\
\text { ir } \\
\text { Sa }\end{array}$ & $\begin{array}{l}\text { requency } \\
\text { in the } \\
\text { Sample }\end{array}$ \\
\hline $\begin{array}{l}\text { Raw Material } \\
\text { Financing }\end{array}$ & $\begin{array}{l}\text { It is a part of inventory financing } \\
\text { whereby the funds are given to } \\
\text { finance raw materials. }\end{array}$ & $\begin{array}{l}\text { Basu and Nair (2012); } \\
\text { More and Basu (2013) }\end{array}$ & 2 \\
\hline $\begin{array}{l}\text { Third Party Logistics } \\
\text { Financing }\end{array}$ & $\begin{array}{l}\text { A logistics service provider buys } \\
\text { goods from a manufacturer and } \\
\text { obtains an interim legal ownership } \\
\text { before selling them to the } \\
\text { manufacturers' customers after a } \\
\text { certain time. }\end{array}$ & $\begin{array}{l}\text { Caniato et al. (2016); } \\
\text { Song et al. (2016) }\end{array}$ & 2 \\
\hline $\begin{array}{c}\text { Dynamic } \\
\text { Discounting }\end{array}$ & $\begin{array}{l}\text { "Dynamic Discounting (DD) utilises } \\
\text { trade process visibility granted by an } \\
\text { information and communication } \\
\text { technology (ICT) platform to allow } \\
\text { the dynamic settlement of invoices in } \\
\text { a buyer-supplier relationship." }\end{array}$ & Gelsomino et al. (2016a) & 2 \\
\hline $\begin{array}{c}\text { Early Payment } \\
\text { Discount Program }\end{array}$ & $\begin{array}{l}\text { A programme in which the supplier } \\
\text { offers a cash discount to encourage } \\
\text { the buyer to pay quickly. }\end{array}$ & Ho et al. (2008) & 2 \\
\hline Buy Back Guarantee & $\begin{array}{l}\text { "It refers to a kind of supply chain } \\
\text { financing [in which] the bank helps } \\
\text { the capital-constrained retailer settle } \\
\text { the payment, based on the core } \\
\text { supplier's buyback guarantee." }\end{array}$ & Chen et al. (2017) & 2 \\
\hline Credit Guarantee & $\begin{array}{l}\text { "A credit guarantee where the } \\
\text { deep-pocket manufacturer represents } \\
\text { a promise of timely payment for the } \\
\text { retailer with high default risks in the } \\
\text { supply chain." }\end{array}$ & Yan et al. $(2014,2017)$ & 2 \\
\hline Bank Guarantee & $\begin{array}{l}\text { A bank guarantee is a promise from } \\
\text { the debtor's bank that the liabilities } \\
\text { of the debtor will be met in the event } \\
\text { of failure to repay. }\end{array}$ & Martin and Hofmann (2017) & 1 \\
\hline $\begin{array}{l}\text { Manufacturer } \\
\text { Collateral }\end{array}$ & $\begin{array}{l}\text { "The manufacturer assumed to be } \\
\text { the core enterprise of a chain, } \\
\text { provides her retailer with collateral } \\
\text { to help him borrow from the bank at } \\
\text { a low-interest rate." }\end{array}$ & Bi et al. (2018a) & 1 \\
\hline Supplier's Subsidy & $\begin{array}{l}\text { The supplier allows the retailer a } \\
\text { delay in payment, and provides a } \\
\text { subsidy contract to alleviate its } \\
\text { problems if it is profitable. }\end{array}$ & Bi et al. (2018a) & 1 \\
\hline Pre-selling & $\begin{array}{l}\text { In a preselling program, firms offer } \\
\text { to sell their products, possibly at a } \\
\text { discounted wholesale price, long } \\
\text { before the selling season. }\end{array}$ & Xiao and Zhang (2018) & 1 \\
\hline Trade Credit & $\begin{array}{l}\text { Trade credit is a short-term loan } \\
\text { between firms that are tied in both } \\
\text { timing and value to the exchange of } \\
\text { goods between them. It occurs when } \\
\text { there is a delay between the delivery } \\
\text { of goods or the provision of services } \\
\text { by a supplier and their payment. }\end{array}$ & $\begin{array}{l}\text { Ferris (1981); and } \\
\text { García-Teruel and Martínez-Solano } \\
\text { (2010) }\end{array}$ & 1 \\
\hline
\end{tabular}


Reverse factoring is the most widely discussed solution in the supply chain literature (Liebl et al. 2016; Lekkakos and Serrano 2016; Caniato et al. 2016; Iacono et al. 2015; Grüter and Wuttke 2017; Popa 2013; de Goeij et al. 2016). In fact, there are some articles that considered reverse factoring to be SCF. Gelsomino et al. (2016b) put it as 'buyer-driven perspective', which is a subset of the financial-oriented perspective of SCF. Besides, there are other solutions mentioned, such as payables discounting (Silvestro and Lustrato 2014), approved payables financing (Martin 2017), and payables extension finance (Basu and Nair 2012; More and Basu 2013), which in substance are similar to reverse factoring, i.e., based on payables.

Several articles also focused on 'accounts receivables financing', which is the mode of financing in which enterprises use receivables as the underlying asset (Basu and Nair 2012; Popa 2013; More and Basu 2013; Silvestro and Lustrato 2014; Wang 2017). Two forms of accounts receivables financing are evident from the literature, i.e., accounts receivables pledging and accounts receivables factoring. Although factoring may be a part of accounts receivables financing, various articles touched on factoring specifically as the mode of financing (Caniato et al. 2016; Tang et al. 2018; Martin and Hofmann 2017; Yu and Ma 2015).

The suppliers may avail of financing using the 'purchase orders' before the repayment period from the buyers. This form of financing is known as 'purchase order financing' (Basu and Nair 2012; More and Basu 2013; Silvestro and Lustrato 2014; Tang et al. 2018; Babich and Kouvelis 2018).

Supply chain finance may also be used to finance the agricultural supply chain, and is known as 'agricultural supply chain finance'. Karyani et al. (2015) and Karyani et al. (2016) categorised it into 'pre-harvest financing' and 'trade services financing'. Suayb Gundogdu (2010), while studying the Islamic structured trade finance on cotton production, grouped the financing modes into pre-harvest (Salam) and post-harvest (Murabaha and Mursharakah). Zhou et al. (2018) grouped agricultural supply chain finance into four categories: microcredit, microloans, supply chain and industrial model, and online and offline lending.

One of the solutions through which SCF can take place is through the online platform. It could be a platform through which e-factoring or e-reverse factoring could take place, or it may occur in the form of peer-to-peer lending, or where the smaller supplier or retailer may get a necessary funding from their SC partner, which could be buyer or manufacturer (Wuttke et al. 2013a; Hofmann and Zumsteg 2015; Martin and Hofmann 2017; Tsai and Peng 2017; Gao et al. 2018). Caniato et al. (2016) also dwelled on the online form of SCF by calling them an 'advanced form of reverse factoring' and 'seller-based invoice auction'. The online platform could also be that which connects the supply chain partners, i.e., buyer, supplier, and service provider, where the documentary process involved in the transactions could be managed more quickly, visibly, and cost-effectively. Yuan (2007) did a case study on the TradeCard solution, which helps connect the supply chain partners through better managing the documentary process of international transactions. TradeCard is stated to be replacing letters of credit or open accounts in international transactions.

Suppliers may avail funding through 'inventory financing', which uses inventory as an underlying asset (Li et al. 2011; Popa 2013; Tang et al. 2018; Babich and Kouvelis 2018; Chen and Kieschnick 2018). Warehousing financing is also another popular form of financing where the concerned party may avail financing by generally pledging the warehouse receipt (Popa 2013; Luo et al. 2015; Jiang et al. 2016; Chen and Wen 2017).

Buyer direct financing is a mode through which a seller may avail funds from the buyer through advances or loans, and has also been discussed in several articles (Popa 2013; Tang et al. 2018; Babich and Kouvelis 2018; Chen and Kieschnick 2018).

Besides the above-mentioned solutions of SCF, the literature on SCF revealed several solutions such as vendor-managed inventory (Basu and Nair 2012; More and Basu 2013; Caniato et al. 2016), raw material financing (Basu and Nair 2012), third-party logistics financing (Basu and Nair 2012; More and Basu 2013), dynamic discounting (Caniato et al. 2016; Martin and Hofmann 2017), early payment discount programmes (Basu and Nair 2012; More and Basu 2013), 
buy-back guarantees (Chen et al. 2017; Yu and Ma 2015), credit guarantees (Yan et al. 2017), bank guarantees (Martin and Hofmann 2017), manufacturer collateral (Bi et al. 2018a), supplier's subsidy (Bi et al. 2018b); SME closed-loop supply chains (SMECLSCs) (Zhang 2016), and supply chain carbon finance (SCCF) (Yang et al. 2018). Martin (2017) also included letters of credit, bank guarantees, insurances, and credit assessment as risk mitigation aspects of SCF. Trade credit, which is a form of credit offered by the supplier to its buyer in the form of deferred payments, is discussed as 'supplier-led solutions' by Babich and Kouvelis (2018).

Although there are many solutions to SCF, it may be possible to group them based on certain characteristics, e.g., pre-shipment, in-transit, and post-shipment financing (Basu and Nair 2012; More and Basu 2013), traditional and innovative financing solutions (Caniato et al. 2016), traditional and integrated SCF practices (Babich and Kouvelis 2018, and buyer-led and supplier-led supply chain finance (Babich and Kouvelis 2018).

\section{Contribution to the Existing Literature}

Our study contributes to the existing literature on supply chain finance, and extends the work of Gelsomino et al. (2016b) and Xu et al. (2018) in the following ways. 1. We identified and consolidated the factors that influence SCF. Further, we also grouped these factors into five categories based on certain common characteristics. This grouping can help simplify the understanding of the factors. 2. The current study also identified various outcomes that could emerge out of the use of SCF. We did not limit ourselves only to the expected benefits resulting out of the SCF. 3. We also addressed the question: what constitutes the supply chain finance solutions? We identified several SCF solutions that have been discussed in the extant literature. In addition, we also showed which solutions are most widely discussed and which are understudied.

\section{Managerial Implications}

We believe our study offers managerial implications in the following ways. 1. The parties involved in the supply chain finance, whether the supplier, buyer, financial service provider, or technology service provider, can understand the important factors that influence the use of SCF. This study can help them concentrate on these factors to improve the adoption and effectiveness of SCF. 2 . The parties can understand the expected outcome when SCF is implemented. Understanding this is crucial, as it can improve and enhance the adoption of SCF. For example, SMEs that are generally unaware and reluctant to explore different instruments may be encouraged to participate in SCF. Larger buyers can be encouraged to opt for viewing working capital from the SCF perspective, as it can offer a win-win situation rather than trying to think about its own gain. These buyers may also be able to bring on board their smaller suppliers under SCF by making them aware about the benefits that can be expected out of SCF. FSPs can also know that there are benefits in offering SCF solutions. FSPs and technology service providers can promote their solutions and services better to their potential clients. 3 . We have identified and covered many of the SCF solutions that have been discussed in the literature. This can help create awareness for the suppliers and buyers alike, and increase an interest to explore more of these SCF solutions. Technology service providers may also benefit from knowing the various SCF solutions, and can make better decisions and steps to offer technology-fitting solutions.

\section{Conclusions, Future Directions, and Limitations}

Supply chain finance as a concept has seen a rise in the early 21st century. It received more attention and got a thrust after the financial crisis of September 2008, as the loans from the banks and financial institutions declined considerably. This article reviewed the articles based on three themes: SCF factors, outcomes, and solutions. We used a string of keywords, i.e., "Supply Chain Finance" OR "Supply Chain Financing" OR "Financial Supply Chain" OR "Financial Value Chain" and searched the Scopus and Web of Science databases. After removing the duplications, conference proceedings, and the articles that did not meet the themes of the paper, finally, we reviewed 70 research articles. 
We found that analytical and case studies are the most widely used methodologies. There has been a growing interest in the SCF in academics whereby the highest number of publications have come in the last three years. The sources of publications have been quite diverse. Most of the publications have come from the countries such as China, Germany, the USA, and Switzerland. There is a lack of contributions from the regions such as Africa and South America.

The most widely discussed factors in the literature are collaboration, the automation of trade process/level of digitalisation, trust, reputation, image or track record, bargaining power, coordination, financing cost, information sharing, and cooperation, among others. For the simpler understanding of the factors influencing SCF, the authors also classified these factors into five categories, i.e., operational, financial, relationship, technological, and informational factors.

Outcome-wise, a lower cost of financing, reduction in cost, improvement in accessibility to financing, reduction in information asymmetry, improvement in financial performance, and enhancement of profitability were the most recurring areas in the research. Overall, the benefits of SCF can be grouped into financial benefits and non-financial benefits. The Cash-to-Cash cycle (C2C) is a metric that has been widely discussed in the literature to demonstrate the financial benefits of SCF (Randall and Farris 2009; Hofmann and Kotzab 2010; Popa 2013; Silvestro and Lustrato 2014; Hofmann and Zumsteg 2015). C2C is a time-based measure comprised of Days Sales Outstanding (DSO), Days Inventory Outstanding (DIO), and Days Payables Outstanding (DPO).

$$
\mathrm{C} 2 \mathrm{C}=\mathrm{DSO}+\mathrm{DIO}-\mathrm{DPO}
$$

The shorter the $\mathrm{C} 2 \mathrm{C}$, the higher the net present value of cash generated by the assets and the overall increase in the value of the firm will be (Soenen 1993). The C2C metric is a component for enhancing the value of shareholders. C2C optimisation can be approached from a single entity perspective; however, in such cases, the focal firm may end up optimising at the expense of the supply chain partners, and can be counterproductive for the supply chain and the focal firm in the long run. As such, it is vital to view $\mathrm{C} 2 \mathrm{C}$ from a supply chain collaborative perspective. The literature has discussed some of the instances of how SCF can manage C2C optimally at the supply chain level, e.g., shifting the inventory upstream to the suppliers, as the cost of the product is lower upstream in the chain, and the ability to shift inventory further up, even for a few days, will create savings for the entire chain. Some SC partners have strong credit and a lower weighed average cost of capital (WACC), and can reduce the cost of capital of the whole supply chain. Being able to shift the financial needs and burdens of the SC transactions to the partner with lowest WACC will result in an optimal C2C for the SC. Thus, SCF can offer a win-win situation for the SC partners (Randall and Farris 2009; Hofmann and Kotzab 2010). Not only a win-win situation in the case of a dyadic buyer-supplier relationship, but SCF can also create a 'triple win situation' (TWS) when the financial service provider (FSP) is also involved in the SCF, although there are caveats (see Hofmann and Zumsteg 2015).

The literature also revealed that the consequences of SCF might even be negative, and these may be due to risk, uncertainty, and vulnerability.

Amongst the solutions, the most widely covered solutions were reverse factoring, accounts receivables financing, purchase order financing, and agricultural supply chain finance. Although there are lots of SCF solutions, and more are expected to emerge with more innovation and need to improve the financial flow, it is possible to group them based on certain characteristics, e.g., pre-shipment, in-transit, and post-shipment financing; traditional and innovative financing solutions; traditional and integrated SCF practices; or buyer-led and supplier-led supply chain finance.

A lot of work in the literature has been analytical, case study, and simulation-based. We identified several factors from the extant literature; however, more empirical studies will be needed for validation. Although a few articles such as those of Martin (2017) and Wuttke et al. (2013b) have attempted to explain SCF with existing organisational theories, the SCF literature needs more theoretical underpinning, and surveys of the existing theoretical frameworks would be especially beneficial. Innovation diffusion theory (IDT), social exchange theory, and transaction cost theories, among others, 
may be especially worth considering, in order to give a framework for survey research on SCF. Out of the identified factors, some factors may be more critical than others. It will be worth exploring the relationship between these factors. For this, total interpretive structural modelling (TISM)—and with a larger survey dataset, structural equation modelling (SEM) — can be used in the future research. The same can be applied in the case of identified outcomes of SCF. Even the analytical modellings have mostly concentrated on a single period or buyer-supplier or manufacturer-retailer dyads. Future studies may look into a more complicated multi-time period or multi-level in the supply chain. Some of the solutions for SCF such as dynamic discounting, manufacturer collateral, and supplier's subsidy, among others, are very understudied. Most of the studies on SCF have viewed SCF by focussing on single solutions, and it may be possible, especially in empirical studies, to consider more than a single solution. Future research may focus on studying more than a single SCF solution. It may be difficult to take up all of the solutions of SCF, but concentrating on the particular category of SCF solutions, such as buyer-led or supplier-led; pre-shipment or post-shipment, etc. may be more manageable for empirical research. Currently, most of the contributions have come from China, followed by Germany, USA, and Switzerland. However, we found a lack of contributions from regions such as Africa and South America. More research contributions from such regions and countries with lesser contributions will be beneficial for the overall research in supply chain finance. Tsai and Peng (2017) discussed the Fintech revolution and the regulation involved therein by using it as a case study. They viewed Fintech in terms of a larger focal company offering online supply chain financing to their supplier or distributor without the intermediation of banks or financial institutions. However, Fintech companies may not necessarily offer direct financing, but may help in facilitating the SCF by linking the parties in the SCF. More study on the role of Fintechs on SCF and their regulations will be beneficial. All of the studies based on secondary data have been from USA and United Kingdom (UK), and it will be worth exploring the various aspects of SCF such as the expected benefits, risk, and cost, among others, using secondary data from other countries, especially from emerging countries. Another exciting area would be to link SCF with other emerging technologies such as blockchain, the Internet of Things (IoT) and big data.

The limitations of the paper are as follows. 1. The findings of this article are based on a review of 70 papers. We used a search string- "Supply Chain Finance" OR "Supply Chain Financing" OR "Financial Supply Chain" OR "Financial Value Chain"—to identify articles, and this may have caused the exclusion of some of the relevant papers. 2. While performing a qualitative analysis of the documents on the focussed themes, personal biases might have occurred. 3. We also did not include 'grey papers', and this may provide material for further insights into SCF.

Author Contributions: Z.R.M. conceptualised the idea which eventually led to the formulation of research questions, reviewed and tabulated the literature on Supply Chain Finance. He also performed both quantitative and qualitative analysis and worked on the discussions of the results besides offering theoretical and managerial implications of the paper. D.P. offered a valuable contribution in terms of developing the process and framework for literature review, quantitatively analysing the results of the reviewed articles besides editing and refining the drafts of the manuscript.

Funding: This research received no external funding.

Conflicts of Interest: The authors declare no conflict of interest.

\section{References}

Babich, Volodymyr, and Panos Kouvelis. 2018. Introduction to the special issue on research at the interface of finance, operations, and risk management (iFORM): Recent contributions and future directions. Manufacturing E Service Operations Management 20: 1-160.

Bailey, Kate, and Mark Francis. 2008. Managing information flows for improved value chain performance. International Journal of Production Economics 111: 2-12. [CrossRef]

Basu, Preetam, and Suresh K. Nair. 2012. Supply Chain Finance enabled early pay: Unlocking trapped value in B2B logistics. International Journal of Logistics Systems and Management 12: 334-53. [CrossRef] 
Bi, Gongbing, Yalei Fei, Xiaoyong Yuan, and Dong Wang. 2018a. Joint operational and financial collaboration in a capital-constrained supply chain under manufacturer collateral. Asia-Pacific Journal of Operational Research 35: 1850010. [CrossRef]

Bi, Gongbing, Ping Chen, and Yalei Fei. 2018b. Optimal decisions and coordination strategy of a capital-constrained supply chain under customer return and supplier subsidy. Journal of Modelling in Management 13: 278-301. [CrossRef]

Blackman, Ian D., and Christopher Holland. 2006. The management of financial supply chains: From adversarial to co-operative strategies. In Project E-Society: Building Bricks. Boston: Springer, pp. 82-95.

Boissay, Frederic, and Reint Gropp. 2007. Trade credit defaults and liquidity provision by firms. ECB Working Paper No. 753, May 31.

Budin, Morris, and A. T. Eapen. 1970. Cash Generation in Business Operations: Some Simulation Models. The Journal of Finance 25: 1091-107. [CrossRef]

Camerinelli, Enrico. 2009. Supply chain finance. Journal of Payments Strategy E Systems 3: 114-28.

Caniato, Federico, Luca Mattia Gelsomino, Alessandro Perego, and Stefano Ronchi. 2016. Does finance solve the supply chain financing problem? Supply Chain Management: An International Journal 21: 534-49. [CrossRef]

Carnovale, Steven, and Sengun Yeniyurt. 2015. The impact of supply network structure on the financial performance of the firm. In Supply Chain Forum: An International Journal. Abingdon: Taylor \& Francis, vol. 16, No. 3. pp. 18-28.

Chen, Qianqian. 2016. A Supply Chain Financial Service Management Model of Chinese Logistics Enterprises. International Journal of Simulation Systems, Science E Technology 17. [CrossRef]

Chen, Chongyang, and Robert Kieschnick. 2018. Bank credit and corporate working capital management. Journal of Corporate Finance 48: 579-96. [CrossRef]

Chen, Hualiang, and Jianbo Wen. 2017. Financing Model Analysis and Risk Management of Supply Chain Finance Based on Gray Evaluation. Revista de la Facultad de Ingeniería 10: 95-105.

Chen, Jianxin, Yong-Wu Zhou, and Yuanguang Zhong. 2017. A pricing/ordering model for a dyadic supply chain with buyback guarantee financing and fairness concerns. International Journal of Production Research 55: 5287-304. [CrossRef]

Claassen, Marloes JT, Arjan J. Van Weele, and Erik M. Van Raaij. 2008. Performance outcomes and success factors of vendor managed inventory (VMI). Supply Chain Management: An International Journal 13: 406-14. [CrossRef]

Coricelli, Fabrizio, and Igor Masten. 2004. Growth and volatility in transition countries: The role of credit. In Festschrift in Honor of Guillermo A. Calvo. Washington DC: International Monetary Fund, April.

de Goeij, Christiaan A. J., Alexander T. C. Onstein, and Michiel A. Steeman. 2016. Impediments to the Adoption of Reverse Factoring for Logistics Service Providers. In Logistics and Supply Chain Innovation. Cham: Springer, pp. 261-77.

Denyer, David, and David Tranfield. 2009. Producing a systematic review. In The SAGE Handbook of Organizational Research Methods. Edited by David A. Buchanan and Alan Bryman. London: Sage Publications, pp. 671-89.

Ding, Zhaohan, Huidi Li, and Junqing Zhu. 2017. Research on the Framework of Supply Chain Finance Operation Model of E-commerce Enterprises by Taking JD as An Example. Boletín Técnico 55: 7-13.

Fabbri, Daniela, and Leora F. Klapper. 2016. Bargaining power and trade credit. Journal of Corporate Finance 41: 66-80. [CrossRef]

Fairchild, Alea. 2005. Intelligent matching: Integrating efficiencies in the financial supply chain. Supply Chain Management: An International Journal 10: 244-48. [CrossRef]

Ferris, J. Stephen. 1981. A transactions theory of trade credit use. The Quarterly Journal of Economics 96: $243-70$. [CrossRef]

Gao, Guang-Xin, Zhi-Ping Fan, Xin Fang, and Yun Fong Lim. 2018. Optimal Stackelberg strategies for financing a supply chain through online peer-to-peer lending. European Journal of Operational Research 267: 585-97. [CrossRef]

García-Teruel, Pedro Juan, and Pedro Martínez-Solano. 2010. Determinants of trade credit: A comparative study of European SMEs. International Small Business Journal 28: 215-33. [CrossRef]

Gelsomino, Luca M., Riccardo Mangiaracina, Alessandro Perego, and Angela Tumino. 2016a. Supply Chain Finance: Modelling a Dynamic Discounting Programme. Journal of Advanced Management Science 4. [CrossRef] 
Gelsomino, Luca Mattia, Riccardo Mangiaracina, Alessandro Perego, and Angela Tumino. 2016b. Supply chain finance: A literature review. International Journal of Physical Distribution E Logistics Management 46: 348-66.

Global Supply Chain Finance Forum. n.d. In Brief Standard Definition. Global Supply Chain Forum. Available online: http:/ / supplychainfinanceforum.org/ (accessed on 18 September 2018).

Gomm, Moritz Leon. 2010. Supply chain finance: Applying finance theory to supply chain management to enhance finance in supply chains. International Journal of Logistics: Research and Applications 13: 133-42. [CrossRef]

Grüter, Robert, and David A. Wuttke. 2017. Option matters: Valuing reverse factoring. International Journal of Production Research 55: 6608-23. [CrossRef]

Haley, W. Charles, and Robert C. Higgins. 1973. Inventory policy and trade credit financing. Management Science 20: 464-71. [CrossRef]

Ho, Chia-Huei, Liang-Yuh Ouyang, and Chia-Hsien Su. 2008. Optimal pricing, shipment and payment policy for an integrated supplier-buyer inventory model with two-part trade credit. European Journal of Operational Research 187: 496-510. [CrossRef]

Hofmann, Erik. 2005. Supply chain finance: Some conceptual insights. In Beiträge Zu Beschaffung Und Logistik. Wiesbaden: Springer Gabler, pp. 203-14.

Hofmann, Erik, and Jan Bosshard. 2017. Supply chain management and activity-based costing: Current status and directions for the future. International Journal of Physical Distribution \& Logistics Management 47: 712-35.

Hofmann, Erik, and Herbert Kotzab. 2010. A supply chain-oriented approach of working capital management. Journal of business Logistics 31: 305-30. [CrossRef]

Hofmann, Erik, and Stefan Zumsteg. 2015. Win-win and no-win situations in supply chain finance: The case of accounts receivable programs. In Supply Chain Forum: An International Journal. Abingdon: Taylor \& Francis, vol. 16, No. 3. pp. 30-50.

Huff, Jerry, and Dale S. Rogers. 2015. Funding the organization through supply chain finance: A longitudinal investigation. In Supply Chain Forum: An International Journal. Abingdon: Taylor \& Francis, vol. 16, No. 3. pp. 4-17.

Iacono, Dello Umberto, Matthew Reindorp, and Nico Dellaert. 2015. Market adoption of reverse factoring. International Journal of Physical Distribution \& Logistics Management 45: 286-308.

Jiang, Jia, Yibo Jin, and Chen Yang Dong. 2016. Research on the e-business logistics service mode based on branch storage and warehouse financing. International Journal of Services Technology and Management 22: 203-17. [CrossRef]

Johnson, M. Eric. 2008. Information risk of inadvertent disclosure: An analysis of file-sharing risk in the financial supply chain. Journal of Management Information Systems 25: 97-124. [CrossRef]

Karyani, Tuti, Eddy Renaldi, Agriani Hermita Sadeli, and Hesty Nurul Utami. 2015. Design of Supply Chain Financing Model of Red Chili Commodity with Structured Market Orientation. Abstrak 13: 6187-200.

Karyani, Tuti, Hesty N. Utami, Agriani H. Sadeli, Elly Rasmikayati, Sulistyodewi, and Nur Syamsiyah. 2016. Mango Agricultural Supply Chain: Actors, Business Process and Financing Scheme. IJABER 14: 7751-64.

Klapper, Leora. 2006. The role of factoring for financing small and medium enterprises. Journal of Banking and Finance 30: 3111-30. [CrossRef]

Lamoureux, Jean-François, and Todd Evans. 2011. Supply chain finance: A new means to support the competitiveness and resilience of global value chains. Available online: https:/ / ssrn.com/abstract=2179944 (accessed on 12 October 2011).

Lekkakos, Spyridon Damianos, and Alejandro Serrano. 2016. Supply chain finance for small and medium sized enterprises: The case of reverse factoring. International Journal of Physical Distribution $\mathcal{E}$ Logistics Management 46: 367-92.

Li, Guojuan. 2017. Research on Credit Ratings of Small and Medium-sized Enterprises Based on Supply-chain Finance. Agro Food Industry Hi-Tech 28: 2440-43.

Li, Yixue, Shouyang Wang, Gengzhong Feng, and Kin Keung Lai. 2011. Comparative analysis of risk control in logistics and supply chain finance under different pledge fashions. International Journal of Revenue Management 5: 121-44. [CrossRef]

Liebl, John, Evi Hartmann, and Edda Feisel. 2016. Reverse factoring in the supply chain: Objectives, antecedents and implementation barriers. International Journal of Physical Distribution E Logistics Management 46: $393-413$. 
Liu, Qingtao, and Jianbo Wen. 2017. Supply Chain Financial Ecosystem Analysis Based on Cusp Catastrophe Model. Revisa de la Facultad de Ingeniería 32: 12-21.

Luo, Yong, Zhiya Chen, and Changxin Chen. 2015. Robust optimization in warehouse space allocation of pledges in supply chain financing. Advances in Transportation Studies 1: 99-110.

Maloni, Michael, and Wilhelm C. Benton. 2000. Power influences in the supply chain. Journal of Business Logistics 21: 49-74.

Martin, Judith. 2017. Suppliers' participation in supply chain finance practices: Predictors and outcomes. International Journal of Integrated Supply Management 11: 193-216. [CrossRef]

Martin, Judith, and Erik Hofmann. 2017. Involving financial service providers in supply chain finance practices: Company needs and service requirements. Journal of Applied Accounting Research 18: 42-62. [CrossRef]

More, Dileep, and Preetam Basu. 2013. Challenges of supply chain finance: A detailed study and a hierarchical model based on the experiences of an Indian firm. Business Process Management Journal 19: 624-47. [CrossRef]

Pellegrino, Roberta, Nicola Costantino, and Danilo Tauro. 2018. Supply Chain Finance: A supply chain-oriented perspective to mitigate commodity risk and pricing volatility. Journal of Purchasing and Supply Management. In press. [CrossRef]

Pfohl, Hans-Christian, and Moritz Gomm. 2009. Supply chain finance: Optimizing financial flows in supply chains. Logistics Research 1: 149-61. [CrossRef]

Popa, Virgil. 2013. The financial supply chain management: A new solution for supply chain resilience. Amfiteatru Economic Journal 15: 140-53.

Protopappa-Sieke, Margarita, and Ralf W. Seifert. 2017. Benefits of working capital sharing in supply chains. Journal of the Operational Research Society 68: 521-32. [CrossRef]

Raddatz, Claudio. 2010. Credit chains and sectoral comovement: Does the use of trade credit amplify sectoral shocks? The Review of Economics and Statistics 92: 985-1003. [CrossRef]

Raghavan, NR Srinivasa, and Vinit Kumar Mishra. 2011. Short-term financing in a cash-constrained supply chain. International Journal of Production Economics 134: 407-12. [CrossRef]

Ramezani, Majid, Ali Mohammad Kimiagari, and Behrooz Karimi. 2014. Closed-loop supply chain network design: A financial approach. Applied Mathematical Modelling 38: 4099-119. [CrossRef]

Randall, Wesley S., and M. Theodore Farris. 2009. Supply chain financing: Using cash-to-cash variables to strengthen the supply chain. International Journal of Physical Distribution E Logistics Management 39: 669-89.

Shang, Kevin H., Jing-Sheng Song, and Paul H. Zipkin. 2009. Coordination mechanisms in decentralized serial inventory systems with batch ordering. Management Science 55: 685-95. [CrossRef]

Shi, Juan, and Qian Wang. 2015. Research on the Risk Analysis of Supply Chain Finance from the Perspective of Encoding Function Forecast. Metallurgical \& Mining Industry 7: 525-30.

Silvestro, Rhian, and Paola Lustrato. 2014. Integrating financial and physical supply chains: The role of banks in enabling supply chain integration. International Journal of Operations \& Production Management 34: 298-324.

Soenen, Luc A. 1993. Cash Conversion Cycle and Corporate Profitability. Journal of Cash Management 13: 53-58.

Song, Zhilan, Huan Huang, Wenxue Ran, and Sen Liu. 2016. A Study on the Pricing Model for 3PL of Inventory Financing. Discrete Dynamics in Nature and Society 2016: 6489748. [CrossRef]

Song, Hua, Kangkang Yu, and Qiang Lu. 2018. Financial service providers and banks' role in helping SMEs to access finance. International Journal of Physical Distribution \& Logistics Management 48: 69-92.

Stemmler, Lars, and Stefan Seuring. 2003. Finanzwirtschaftliche Elemente in der Lieferkettensteuerung-Erste Überlegungen zu einem Konzept des Supply Chain Finance. Logistik Management 5: 27-37.

Suayb Gundogdu, Ahmet. 2010. Islamic structured trade finance: A case of cotton production in West Africa. International Journal of Islamic and Middle Eastern Finance and Management 3: 20-35. [CrossRef]

Ta, Ha, Terry L. Esper, Kenneth Ford, and Sebastian Garcia-Dastuge. 2018. Trustworthiness Change and Relationship Continuity after Contract Breach in Financial Supply Chains. Journal of Supply Chain Management 54: 42-61. [CrossRef]

Tang, Christopher S., S. Alex Yang, and Jing Wu. 2018. Sourcing from suppliers with financial constraints and performance risk. Manufacturing $\mathcal{E}$ Service Operations Management 20: 70-84.

Touboulic, Anne, and Helen Walker. 2015. Theories in sustainable supply chain management: A structured literature review. International Journal of Physical Distribution \& Logistics Management 45: 16-42. 
Tranfield, David, David Denyer, and Palminder Smart. 2003. Towards a methodology for developing evidence-informed management knowledge by means of systematic review. British Journal of Management 14: 207-22. [CrossRef]

Tsai, Chang-Hsien, and Kuan-Jung Peng. 2017. The FinTech Revolution and Financial Regulation: The Case of Online Supply-Chain Financing. Asian Journal of Law and Society 4: 109-32. [CrossRef]

Van der Vliet, Kasper, Matthew J. Reindorp, and Jan C. Fransoo. 2015. The price of reverse factoring: Financing rates vs. payment delays. European Journal of Operational Research 242: 842-53. [CrossRef]

Waller, Matt, M. Eric Johnson, and Tom Davis. 1999. Vendor managed inventory in the retail supply chain. Journal of Business Logistics 20: 183-203.

Wandfluh, Matthias, Erik Hofmann, and Paul Schoensleben. 2016. Financing buyer-supplier dyads: An empirical analysis on financial collaboration in the supply chain. International Journal of Logistics Research and Applications 19: 200-17. [CrossRef]

Wang, Jing. 2017. Current Status and Risk Evaluation of Supply Chain Finance Business in Commercial Banks. Revista de la Facultad de Ingeniería 32: 106-15.

Wang, Yang, Yunlu Ma, and Yuhe Zhan. 2012. Study on supplier-led supply chain finance. Research Journal of Applied Sciences, Engineering and Technology 4: 3375-80.

Wuttke, David A., Constantin Blome, and Michael Henke. 2013a. Focusing the financial flow of supply chains: An empirical investigation of financial supply chain management. International Journal of Production Economics 145: 773-89. [CrossRef]

Wuttke, David A., Constantin Blome, Kai Foerstl, and Michael Henke. 2013b. Managing the innovation adoption of supply chain finance-Empirical evidence from six European case studies. Journal of Business Logistics 34: 148-66. [CrossRef]

Wuttke, David A., Constantin Blome, H. Sebastian Heese, and Margarita Protopappa-Sieke. 2016. Supply chain finance: Optimal introduction and adoption decisions. International Journal of Production Economics 178: 72-81. [CrossRef]

Xiao, Yongbo, and Jihong Zhang. 2018. Preselling to a retailer with cash flow shortage on the manufacturer. Omega 80: 43-57. [CrossRef]

Xu, Xinhan, Xiangfeng Chen, Fu Jia, Steve Brown, Yu Gong, and Yifan Xu. 2018. Supply chain finance: A systematic literature review and bibliometric analysis. International Journal of Production Economics 204: 160-73. [CrossRef]

Yan, Nina, and Baowen Sun. 2013. Coordinating loan strategies for supply chain financing with limited credit. OR Spectrum 35: 1039-58. [CrossRef]

Yan, Nina, and Baowen Sun. 2015. Comparative analysis of supply chain financing strategies between different financing modes. Journal of Industrial and Management Optimization 11: 1073-87. [CrossRef]

Yan, Nina, Hongyan Dai, and Baowen Sun. 2014. Optimal bi-level Stackelberg strategies for supply chain financing with both capital-constrained buyers and sellers. Applied Stochastic Models in Business and Industry 30: 783-96. [CrossRef]

Yan, Nina, Chongqing Liu, Ye Liu, and Baowen Sun. 2017. Effects of risk aversion and decision preference on equilibriums in supply chain finance incorporating bank credit with credit guarantee. Applied Stochastic Models in Business and Industry 33: 602-25. [CrossRef]

Yang, Lei, Yufan Chen, and Jingna Ji. 2018. Cooperation Modes of Operations and Financing in a Low-Carbon Supply Chain. Sustainability 10: 821. [CrossRef]

Yu, Hui, and Yun-lin Ma. 2015. The supply chain finance model-based on the order-to-factoring mode. Systems Engineering-Theory E: Practice 35: 1733-43.

Yu, Jianjun, and Dan Zhu. 2018. Study on the Selection Strategy of Supply Chain Financing Modes Based on the Retailer's Trade Grade. Sustainability 10: 3045. [CrossRef]

Yuan, Soe-Tsyr. 2007. The TradeCard Financial Supply Chain Solution. International Journal of Cases on Electronic Commerce (IJCEC) 3: 48-70. [CrossRef]

Zhang, Cheng. 2016. Small and medium-sized enterprises closed-loop supply chain finance risk based on evolutionary game theory and system dynamics. Journal of Shanghai Jiaotong University (Science) 21: 355-64. [CrossRef]

Zheng, Jianguo, and Jing Zhang. 2017. Analysis on Coordination Mechanism of Supply Chain Finance for B2C Cross-border Ecommerce. Revista de la Facultad de Ingeniería 32: 103-9. 
Zhou, Yongwei, Dayong Wu, and Hehua Fan. 2016. Analysis on Coordination Mechanism of Supply Chain Finance for B2C Cross-border Ecommerce. 17. [CrossRef]

Zhou, Qi, Xiangfeng Chen, and Shuting Li. 2018. Innovative Financial Approach for Agricultural Sustainability: A Case Study of Alibaba. Sustainability 10: 891. [CrossRef] 